\title{
HPLC Microfractionation of Flavones and Antioxidant (Radical Scavenging) Activity of Saccharum officinarum $\mathbf{L}$.
}

\author{
Fabiana C. Vila, Renata Colombo, Tatiana O. de Lira and Janete H. Yariwake* \\ Instituto de Química de São Carlos, Universidade de São Paulo, 13560-970 São Carlos-SP, Brazil
}

\begin{abstract}
A atividade antioxidante do suco de cana-de-açúcar (Saccharum officinarum L.) frente ao reagente DPPH foi avaliada $\left(\mathrm{EC}_{50}\right)$ e as principais substâncias com atividade seqüestradora de radicais livres do suco e extratos de folhas foram identificadas por CLAE-UV/DAD combinada com CLAE-microfracionamento monitorado por CCD, usando $\beta$-caroteno e DPPH como reagentes de detecção. As substâncias mais importantes com atividade seqüestradora de radicais livres foram: nas folhas, luteolina-8- $C$-(ramnosilglucosídeo) (1); no suco, as flavonas diosmetina-8-Cglucosídeo (2), vitexina (3), schaftosídeo (9), isoschaftosídeo (10) e 4',5'-dimetil-luteolina-8-Cglucosídeo (11). O conteúdo de flavonóides totais do suco $(0,241 \pm 0,001 \mathrm{mg}$ flavonóides totais $/ \mathrm{mL}$ suco), comparável ao de outras fontes de flavonóides, sugere o potencial da cana-de-açúcar como fonte alimentícia de antioxidantes naturais. Porém, a baixa capacidade antioxidante da garapa $\left(\mathrm{EC}_{50}=100,2 \pm 2,6 \mathrm{~g} \mathrm{~L}^{-1}\right)$ indica a necessidade de estudos sobre o consumo na dieta e seus efeitos na saúde humana.
\end{abstract}

The antioxidant activity of sugarcane (Saccharum officinarum L.) juice towards DPPH reagent was determined $\left(\mathrm{EC}_{50}\right)$ and the main compounds with radical scavenging activity in juice and leaves extracts were identified by HPLC-UV/PAD analysis combined with HPLC microfractionation monitored by TLC using $\beta$-carotene and DPPH as the detection reagents. In sugarcane leaves, luteolin-8- $C$-(rhamnosylglucoside) (1) was the most important compound with radical scavenging activity; in sugarcane juice, the flavones diosmetin-8-C-glucoside (2), vitexin (3) schaftoside (9), isoschaftoside (10) and 4',5'-dimethyl-luteolin-8-C-glucoside (11) were the most relevant compounds. The content of juice flavonoids $(0.241 \pm 0.001 \mathrm{mg}$ total flavonoids $/ \mathrm{mL}$ juice), comparable to other food sources of flavonoids, suggest the potential of sugarcane as a dietary source of natural antioxidants. However, the low antioxidant ability of sugarcane juice $\left(\mathrm{EC}_{50}=100.2 \pm 2.6 \mathrm{~g} \mathrm{~L}^{-1}\right)$ also points to the need for further studies about the dietary intake of sugarcane flavonoids and its effects on human health.

Keywords: HPLC microfractionation, flavones, Saccharum officinarum L., antioxidant activity, radical scavenging activity

\section{Introduction}

Flavonoids, which are part of the daily human diet, are found in several fruits, vegetables and beverages of plant origin. The study of flavonoid-rich foods has attracted the interest of researchers due to their promising physiological activities, among them as natural antioxidants against free radicals. Their pharmacological properties also account for the growing interest in studying the content of flavonoids in numerous juices, fruits and plant foods. ${ }^{1}$ However, many natural products from Latin American countries, including

\footnotetext{
*e-mail: janete@iqsc.usp.br
}

standardized extracts with a large number of components, still require adequate scientific or clinical research. A recent review illustrates these challenges and presents a compilation of reports concerning the development of a nutritional supplement or functional food from standardized whole-crude mango (Mangifera indica L., Anacardiaceae) extracts. ${ }^{2}$

Sugarcane (a popular name that includes several species of the genus Saccharum L., Poaceae ${ }^{3}$ ) is the most important source of sugar and of raw material for the production of ethanol fuel in Brazil, and is also cultivated commercially in other tropical countries. Former studies on Saccharum spp. have reported the presence of phenolic acids and flavones. ${ }^{3-5}$ The structural elucidation of several 
flavones (aglycones, $C$ - and $O$-glycosides) by LC-UV-MS from Saccharum officinarum L. commercially cultivated in Brazil and also of transgenic plants has been reported by our research group. ${ }^{6,7}$ An HPLC-UV method for the quantification of their flavonoids was fully described, ${ }^{8}$ and this quantitative method was applied to analyze commercially cultivated samples of S. officinarum L. (leaves and bagasse), transgenic plants (leaves) and also sugarcane juice purchased from street vendors (known as "garapa" in Brazil). The flavonoid content in sugarcane juice samples was comparable to other flavonoid-containing beverages such as orange juice and black tea. Moreover, the flavonoid content of leaves and bagasse was considerably high in comparison with other flavonoid sources reported in the literature, such as apples. ${ }^{8}$ These previous findings about sugarcane juice flavonoids have therefore motivated further studies, which are reported herein.

A mixture of high molecular weight alcohols from sugarcane wax has shown antioxidant properties on in vivo models (rats). ${ }^{9}$ Other studies also using in vitro rat models and antioxidant activity assays of phenolic compounds present in sugarcane juice have indicated the potential of sugarcane for beneficial health effects. ${ }^{10}$ The free radical scavenging activity of manufactured sugar products and the identification of polyphenolic compounds by LC-MS has also been reported. ${ }^{11}$

In view of the potential role of sugarcane as a dietary source of flavonoids as well as its possible use as a functional food, this study involved an investigation into the antioxidant activity of Saccharum officinarum L. juice ("garapa") and the identification of active compounds from leaves and juice, using HPLC microfractionation ${ }^{12}$ combined with TLC monitoring of the compounds with antioxidant activity ( $\beta$-carotene test) and free radical scavenging activity (DPPH assays). ${ }^{13}$ HPLC microfractionation consists of collecting the peak from an analytical-scale HPLC separation for more detailed examinations of the compounds on the microgram scale. HPLC microfractionation is a chemical screening strategy that has the disadvantage of requiring more extensive handling of the sample, but which has the advantage of offering the chromatographic conditions developed for hyphenated analyses such as LC-UV-MS and online information to validate structural assignments, combined with the simplicity of TLC bioassays. ${ }^{12,13}$

\section{Experimental}

\section{Plant material}

Leaves of Saccharum officinarum L. (Poaceae) were obtained from a commercial plantation in Araraquara, SP,
Brazil. The plant material was dried to constant weight at about $40{ }^{\circ} \mathrm{C}$ prior to extraction. Samples of sugarcane juice, obtained by crushing cleaned and peeled sugarcane stems, were purchased from an organic plantation at Embrapa Agropecuária Sudeste, São Carlos-SP, Brazil. The juice samples were poured into plastic bottles and frozen at $-10^{\circ} \mathrm{C}$ for storage. Immediately prior to sample preparation, the juice samples were thawed and homogenized.

Sample preparation and quantification of sugarcane juice flavonoids by HPLC-UV/PAD

Sample preparation and quantitative HPLC analyses of total flavonoids in the sugarcane juice followed a procedure previously fully described and optimized. ${ }^{8}$ Samples were filtered through $0.5 \mu \mathrm{m}$ Fluorpore membranes (Millipore) prior to injection of $10 \mu \mathrm{L}$ into the HPLC system. In this work, HPLC analyses were performed using a Waters Alliance 2695 liquid chromatograph system with a photodiode array detector (PAD) 2996 and Empower Pro ${ }^{\circledR}$ version 5.0 for data processing. Separation was performed on a Symmetry column (Waters, Milford, MA, USA) $250 \mathrm{~mm}$ long $\times 4.6 \mathrm{~mm}$ i.d.; $5 \mu \mathrm{m} \mathrm{C}_{18}$ stationary phase) preceded by a guard column $(20 \mathrm{~mm}$ long $\times 3.9 \mathrm{~mm}$ i.d.; $5 \mu \mathrm{m} \mathrm{C}_{18}$ stationary phase). The mobile phase consisted of $0.2 \%$ formic acid (Merck, Darmstadt, Germany) in water (solvent A) and acetonitrile (Tedia Company, Fairfield, USA), (solvent B). The gradient profile used was: 0-8 min: 10 to $13 \% \mathrm{~B}$; $8-25 \mathrm{~min}: 13$ to $20 \% \mathrm{~B} ; 25-40 \mathrm{~min}: 20$ to $40 \% \mathrm{~B}$; 40-45 min: 40-60\% B. All the analyses were performed at a flow rate of $1.0 \mathrm{~mL} \mathrm{~min}^{-1}$, at temperature of $40{ }^{\circ} \mathrm{C}$ and the detection was performed in $350 \mathrm{~nm}$.

Diosmin (Sigma, St. Louis, MO, USA) was utilized for building the analytical curve at concentrations of 5 , $10,15,25,50,100,200,300$ and $400 \mathrm{mg} \mathrm{L}^{-1}$ in DMSO (J. T. Baker, Phillipsburg, NJ, USA) and was analyzed in the same chromatographic conditions used to separation of flavonoids. The results were calculated as $\mathrm{mg}$ total flavonoids (expressed as diosmin)/mL juice. All sugarcane samples were prepared and analysed in triplicate.

\section{HPLC microfractionation}

HPLC microfractionation was performed by a highloading procedure ${ }^{14}$ involving the injection of concentrated leaf and juice extracts into the HPLC analytical-scale system due to the low concentration of flavonoids in extracts obtained after the clean-up step, as previously described. ${ }^{8}$ The methanol fraction $(3 \mathrm{~mL})$ containing the flavonoids obtained by SPE was evaporated on a rotary evaporator to reduce it to about $1 / 4$ of its original volume, and 
filtered through $0.5 \mu \mathrm{m}$ Fluorpore membranes (Millipore) prior to injection $(10 \mu \mathrm{L})$ into the HPLC system. The chromatographic conditions were the same as those described for the quantitative analysis of juice flavonoids. Fractions were collected manually every $5 \mathrm{~min}(5 \mathrm{~mL})$ in Eppendorf tubes, after which all the fractions were evaporated to dryness using a rotatory evaporator prior to the TLC analysis.

\section{TLC analyses of extracts and fractions}

TLC analyses were performed on $0.20 \mathrm{~mm}$-thick silica gel 60 TLC aluminum plates (Merck, Darmstadt, Germany) using ethyl acetate/formic acid/water $(6: 1: 1 \mathrm{v} / \mathrm{v})^{15}$ as mobile phase. Each of the dried fractions obtained after HPLC microfractionation was dissolved in $300 \mu \mathrm{L}$ methanol. Rutin hydrate (95\% pure; Sigma, St. Louis, MO, USA was utilized as standard $\left(100 \mu \mathrm{g} \mathrm{mL} \mathrm{m}^{-1}\right.$ in methanol). For the analysis of leaves fractions, $5 \mu \mathrm{L}$ of the samples and $2 \mu \mathrm{L}$ of the rutin standard were placed on a silica TLC plate using graduated micropipettes Blaubrand (Brand, Wertheim, Germany) while $8 \mu \mathrm{L}$ of sample and $3 \mu \mathrm{L}$ of rutin standard were used for the analysis of juice fractions. After elution, the plates were dried at room temperature and sprayed with detection reagents, $\beta$-carotene or 2,2-diphenyl-1-picrylhydrazil radical (DPPH). ${ }^{13}$ TLC plates were sprayed with an $0.02 \mathrm{mg} \mathrm{mL}^{-1} \beta$-carotene solution in dichloromethane and then exposed to ambient light until the $\beta$-carotene was bleached, indicating the presence of antioxidant compounds. ${ }^{13}$ DPPH radical scavenging activity test was done by spraying a solution of $0.2 \%$ in methanol onto the TLC plate, which was allowed to stand at room temperature until yellow spots appeared, indicating the presence of active compounds. ${ }^{13}$

The limit of detection (LOD) of $\beta$-carotene and DPPH reagents was determined by diluting the standard solution of rutin with methanol (100 $\mu \mathrm{g} \mathrm{mL}^{-1}$ in methanol), in order to obtain solutions with a final concentration of 25,50 and $75 \mu \mathrm{g} \mathrm{mL}-1.2 \mu \mathrm{L}$ of each standard solution of rutin were placed on a silica TLC plate using graduated micropipettes and analyzed by TLC following the above described procedure. The LOD of $\beta$-carotene and DPPH reagents was considered to be the smallest concentration of the rutin solution leading to a visible spot. ${ }^{16}$ The LOD of each reagent was determined in triplicate.

DPPH spectrophotometric assay for evaluation of antioxidant activity

A procedure slightly modified from the method reported by Brand-Williams et al. ${ }^{17,18}$ was followed to evaluate the antioxidant capacity. Sugarcane juice $(100 \mathrm{~mL})$ was mixed with methanol $(10 \mathrm{~mL})$ and sonicated $\left(5 \mathrm{~min}, \mathrm{ca} .25^{\circ} \mathrm{C}\right)$, after which it was centrifuged (10000 rpm, $20 \mathrm{~min}, 25^{\circ} \mathrm{C}$ ) and the resulting supernatant utilized for the antioxidant assay. Aliquots of sample extract $(0.1 \mathrm{~mL})$ in different concentrations (from 35.0 to $195.0 \mathrm{~g} \mathrm{~L}^{-1}$ ) were added to $3.9 \mathrm{~mL}$ of a DPPH solution (0.025 $\mathrm{g} \mathrm{L}^{-1}$ in methanol). The mixture was shaken vigorously and allowed to stand in the dark at room temperature for $1 \mathrm{~h}$. The decrease in absorbance of the resulting solution was monitored at $515 \mathrm{~nm}$ after $1 \mathrm{~h}$ of reaction, using a Perkin Elmer UV-Vis model Cary 5G spectrophotometer. The blank solution consisted of $0.1 \mathrm{~mL}$ of methanol and $3.9 \mathrm{~mL}$ of a DPPH radical solution. A fresh DPPH radical stock solution was prepared each day. The percentage of scavenged DPPH was calculated from equation $1,{ }^{19}$

$D P P H_{\text {scavenging }}^{s} \%=\left(A o-A_{S} / A o\right) \times 100$

where $A o$ is absorbance of the blank and $A_{S}$ is absorbance of the sample at $515 \mathrm{~nm}$.

The percentage of scavenged DPPH was then plotted against the sample concentration to calculate graphically the amount of antioxidant required to decrease the initial DPPH concentration by $50 \%\left(\mathrm{EC}_{50}\right)$, expressed in terms of concentration $\left(\mathrm{g} \mathrm{L}^{-1}\right)$. Rutin in a concentration ranging from 0.06 to $1.00 \mathrm{~g} \mathrm{~L}^{-1}$ was used as the standard, following the same procedure described for the sugarcane extracts.

\section{Results and Discussion}

\section{HPLC analyses}

The flavonoid peaks in the samples studied here were identified by comparing the HPLC retention time and the UV-Vis/PAD spectra (Figure 1 and Table 1) against the data described by Colombo et al., ${ }^{6,7}$ obtained in the same chromatographic conditions and confirmed by LChyphenated techniques (HPLC-UV-MS). The UV spectra of flavonoids (see Supplementary Information) are a very helpful feature for the unequivocal identification of flavonoid peaks, with two characteristic absorption bands (Band II, $\lambda_{\max }$ between 240 and $280 \mathrm{~nm}$ and Band I, 300 to $380 \mathrm{~nm}) .{ }^{20}$

In addition to analyzing the antioxidant activity of sugarcane juice, the total flavonoids in the juice were also quantified, since previous quantitative data on sugarcane juice flavonoids were obtained only for commercial samples purchased from street vendors. ${ }^{8}$ No relevant difference was found here in the structure of the juice compounds, but a smaller amount of total flavonoids was observed (Table 2). 

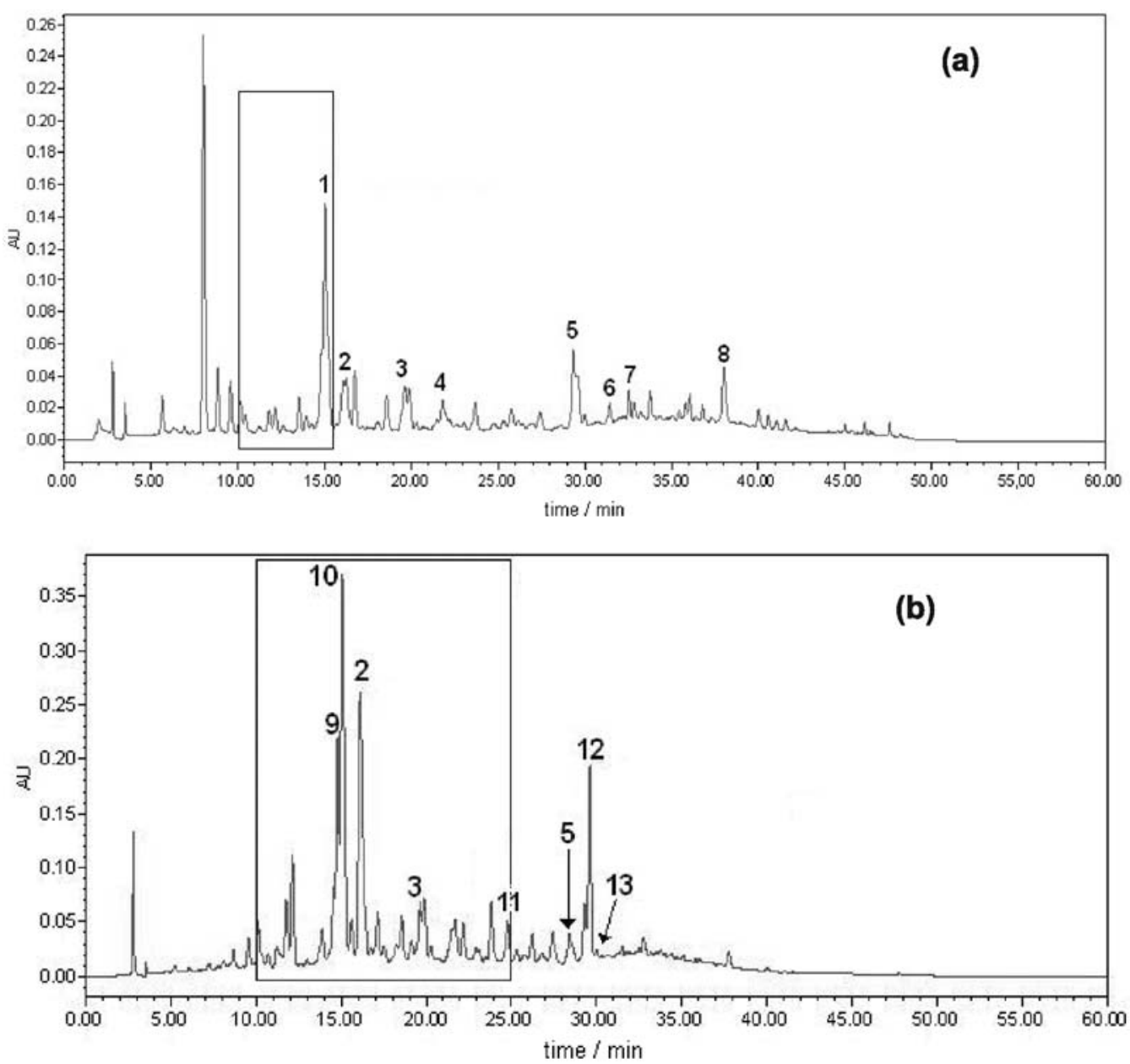

Figure 1. HPLC profile (detection at $350 \mathrm{~nm}$ ) of Saccharum officinarum L. extracts (a) leaves; (b) sugarcane juice. The regions highlighted in the chromatograms showed radical scavenging activity (DPPH test). Chromatographic conditions as described in Materials and Methods. For identification of the peaks, see Table 1 .

Table 1. Flavonoids identified in Saccharum officinarum L. extracts and their respective UV/PAD data

\begin{tabular}{|c|c|c|c|c|}
\hline \multirow{2}{*}{$\begin{array}{c}\text { Peak } \\
\text { number }\end{array}$} & \multirow{2}{*}{ Sample } & \multicolumn{2}{|c|}{$\lambda_{\max } /(\mathrm{nm})$} & \multirow{2}{*}{ Compound } \\
\hline & & Band I & Band II & \\
\hline 1 & leaves & 337 & 270 & luteolin-8-C-(rhamnosylglucoside) \\
\hline 2 & leaves, juice & 346 & 268 & diosmetin-8-C-glucoside \\
\hline 3 & leaves, juice & 329 & 271 & vitexin \\
\hline 4 & leaves, & 329 & 271 & orientin \\
\hline 5 & leaves, juice & 351 & 264 & tricin-7- $O$-neohesperidoside \\
\hline $6 / 7$ & leaves & 328,327 & 271 & tricin-4'-O-(erythro or threo guaiacylglyceryl) ether-7-O-glucopyranoside \\
\hline 8 & leaves & 343 & 269 & tricin-4'-O-(erythro or threo guaiacylglyceryl) ether \\
\hline 9 & juice & 335 & 270 & schaftoside \\
\hline 10 & juice & 335 & 270 & isoschaftoside \\
\hline 11 & juice & 345 & 270 & $4^{\prime}, 5^{\prime}$-di- $O$-methyl-luteolin-8-C-glucoside \\
\hline 12 & juice & 337 & 270 & tricin-7-O-rhamnosylgalacturonide \\
\hline 13 & juice & 350 & 266 & tricin-7-O-glucoside \\
\hline
\end{tabular}

The differences between the quantitative data obtained in this study and in the former one suggest variations in sugarcane juice flavonoid content due to factors such as sugarcane cultivars, growth conditions etc., which are unknown for commercial juice samples. All the peaks exhibiting UV spectra characteristic of flavonoids and 
with an area greater than LOQ $\left(0.83 \mathrm{mg}\right.$ diosmin $\mathrm{L}^{-1}$; LOQ value calculated taking into account a signal-tonoise ratio of 10:1) were considered in the determination of total flavonoids (Table 2). A calibration curve was built using diosmin as the standard, and the detector's response at $350 \mathrm{~nm}$ was linear from 5 to $400 \mathrm{mg}$ diosmin $\mathrm{L}^{-1}$. The regression equation was found to be $y=1.26 .10^{4} \mathrm{x}-6.64 .10^{4}$ $(r=0.9999)$, with a variation coefficient below $2 \%$ for the triplicate analysis. Table 2 shows the individual content of the flavones that exhibited radical scavenging activity.

HPLC microfractionation of the main compounds with radical scavenging activity and evaluation of the antioxidant activity $\left(E C_{50}\right)$ of sugarcane juice

Preliminary TLC tests showed low sensitivity of $\beta$-carotene to detect antioxidant compounds, and the LOD of $\beta$-carotene proved to be $100 \mathrm{mg} \mathrm{L}^{-1}$, while the LOD of DPPH was $75 \mathrm{mg} \mathrm{L}^{-1}$ using rutin as the standard (see also Material and Methods - TLC). Therefore, further TLC tests of sugarcane samples were carried out using DPPH reagent. However, even using DPPH reagent, the injected samples had to be overloaded for the effective detection of compounds with radical scavenging activity by TLC, due to the small amount obtained in each fraction. A total of ten fractions from each extract were collected and the radical scavenging activity was detected in the regions highlighted in the chromatograms of Figure 1. The major compound found in the region with the most intense spot showing radical scavenging activity $\left(\mathrm{t}_{\mathrm{R}}\right.$ between $10-15 \mathrm{~min}$ and area corresponding to $31.93 \%$ of the flavonoid peaks, Figure 1a) was flavone luteolin-8- $C$-(rhamnosylglusoside) (1), which corresponds to $23 \%$ of total leaves flavonoids and is therefore probably related to the overall antioxidant properties of the leaves extract.

The juice extract displayed the most significant radical scavenging activity in the fractions collected in the interval of $t_{R}=10-25 \mathrm{~min}$, which corresponds to $81.80 \%$ of the flavonoid peaks (Figure 1b) and five flavones, diosmetin-8C-glycoside (2), vitexin (3), schaftoside (9), isoschaftoside
(10) and 4',5'-di- $O$-methyl-luteolin-8- $C$-glycoside (11), corresponding to $58.28 \%$ of the total juice flavonoids, were identified. In the second HPLC microfractionation the isomeric pair schaftoside (9)-isochaftoside (10) was not separated, but it was possible to collect diosmetin8-C-glycoside (2), vitexin (3) and 4',5'-di- $O$-methylluteolin-8-C-glycoside (11) separately. TLC testing of the fractions containing the compounds $2,3,9 / 10$ and 11 confirmed their radical scavenging activity, attesting to the feasibility of HPLC microfractionation as an analyticalscale procedure for obtaining enriched fractions for further assays.

On the other hand, TLC data is a screening and qualitative step, that needs to be supported by testing in the actual substrate, ${ }^{21}$ so a quantitative assay of the overall activity of sugarcane juice was also done. The antioxidant activity of sugarcane juice was evaluated in terms of hydrogen-donating or radical-scavenging ability, using the DPPH method developed by Brand-Williams et al. ${ }^{17,18}$ with a few modifications and rutin as a reference antioxidant compound. The percentage of antioxidant activity corresponds to the amount of DPPH consumed by the antioxidant compound, and the amount of antioxidant necessary to decrease the initial DPPH concentration by $50 \%$ is called efficient concentration $\left(\mathrm{EC}_{50}\right)$. The higher the consumption of DPPH by a given sample, the lower the $\mathrm{EC}_{50}$ value and the higher its antioxidant ability.

Sugarcane juice showed $\mathrm{EC}_{50}=100.2 \pm 2.6 \mathrm{~g} \mathrm{~L}^{-1}$, indicating antioxidant activity, although it was lower than rutin $\left(\mathrm{EC}_{50}=0.172 \pm 0.43 \mathrm{~g} \mathrm{~L}^{-1}\right)$. The difference between the activity of sugarcane juice and rutin must take into account the higher purity of the reference compound (rutin, $95 \%$ purity) while the sugarcane juice analyzed is a crude extract containing other compounds that are not necessarily proton and electron donors, e.g., sugars, mixed with the active compounds. Since the total flavonoids content corresponds to about $0.11 \%(\mathrm{~m} / \mathrm{m})$ of the juice $(0.241 \pm$ $0.001 \mathrm{mg}$ flavonoids $\mathrm{mL}^{-1}$ juice, Table 2), the value of $\mathrm{EC}_{50}$ of sugarcane juice suggests a direct correlation between the (low) antioxidant activity of sugarcane juice and the

Table 2. Quantitative data about sugarcane juice flavonoids with radical scavenging activity (DPPH test)

\begin{tabular}{|c|c|c|}
\hline Peak number & Identification & $\begin{array}{l}\text { Flavonoid content (mean } \pm \mathrm{dp})^{\mathrm{a}} \\
\quad(\mathrm{mg} \text { flavonoid/mL juice })\end{array}$ \\
\hline 2 & diosmetin-8-C-glucoside & $0.007 \pm 0.001$ \\
\hline 3 & vitexin & $0.008 \pm 0.001$ \\
\hline 9 & schaftoside & $0.017 \pm 0.001$ \\
\hline 10 & isoschaftoside & $0.043 \pm 0.001$ \\
\hline 11 & $4^{\prime}, 5^{\prime}$-di-O-methyl-luteolin-8-C-glucoside & $0.008 \pm 0.001$ \\
\hline \multicolumn{2}{|c|}{ Total flavonoids (juice) } & $0.241 \pm 0.001$ \\
\hline
\end{tabular}

${ }^{a} n=3$; data are expressed as $\mathrm{mg}$ diosmin/mL juice. 
sugarcane flavonoids content. This content is low, but it includes compounds with radical scavenging activity (see Table 2) as demonstrated by the microfractionation monitored by TLC and DPPH reagent.

\section{Conclusions}

The overall findings reported here on the antioxidant (radical scavenging) activity of sugarcane juice and the flavones obtained by HPLC microfractionation, allied to in vivo data, ${ }^{10}$ may justify further studies of the potential of sugarcane juice as a natural source of antioxidant compounds. However, the low $\mathrm{EC}_{50}$ value of sugarcane juice also indicates the need for detailed nutritional or physiological studies about the consumption of sugarcane juice and its effects on human health. HPLC microfractionation offers the significant advantage of being performed on an analytical-scale without requiring any additional optimization of chromatographic conditions, allowing the chromatographic data obtained here (retention time, UV/PAD spectra) to be combined with data obtained under similar chromatographic conditions. ${ }^{6,7}$ These results encourage the use of HPLC microfractionation as a complementary tool in the study of bioactive compounds in other Brazilian food or medicinal plants.

\section{Acknowledgments}

The authors wish to thank FAPESP (Proc. 02/00493-2) and $\mathrm{CNPq}$ (research fellowship to J. H. Y.) for financial support.

\section{Supplementary Information}

Supplementary data are available free of charge as a PDF file at http://jbcs.sbq.org.br.

\section{References}

1. Robards, K.; Antolovich, M.; Analyst 1997, 122, 11R.

2. Núñez-Sellés, A. J.; J. Braz. Chem. Soc. 2005, 16, 699.
3. Smith, P.; Paton, N. H.; Sugar Technol. Rev. 1985, 12, 117.

4. Mabry, T. J.; Liu, Y. L.; Pearce, J.; J. Nat. Prod. 1984, 47, 127.

5. McGhie, T. K.; J. Chromatogr. 1993, 634, 107.

6. Colombo, R.; Yariwake, J. H.; Queiroz, E. F.; Ndjoko, K.; Hostettmann, K.; J. Chromatogr. A 2005, 1082, 51.

7. Colombo, R.; Yariwake, J. H.; Queiroz, E. F.; Ndjoko, K.; Hostettmann, K.; Phytochem. Anal. 2006, 17, 337.

8. Colombo, R.; Yariwake, J. H.; Lanças, F. M.; J. Chromatogr. A 2006, 1103, 118.

9. Noa, M.; Mendoza, S.; Mas, R.; Mendoza, N.; Drugs Exp. Clin. Res. 2002, 28, 177.

10. Duarte-Almeida, J. M.; Novoa, A. V.; Linares, A. F.; Lajolo, F. M.; Genovese, M. I.; Plant Food Hum. Nutr. 2006, 61, 187.

11. Payet, B.; Sing, A. S. C.; Smadia, J.; J. Agric. Food Chem. 2006, 54, 7270 .

12. Wolfender, J. -L.; Queiroz, E. F.; Hostettmann, K.; Magn. Reson. Chem. 2005, 43, 697.

13. Hostettmann, K.; Terreaux, C.; Marston, A.; Potterat, O.; J. Planar Chromatogr. 1997, 10, 251.

14. Queiroz, E. F.; Ioset, J. R.; Ndjoko, K.; Guntern, A.; Foggin, C. M.; Hostettmann, K.; Phytochem. Anal. 2005, 16, 166.

15. Brasseur, T.; Angenot, L.; J. Chromatogr. 1986, 351, 351.

16. Poole, C. F.; Poole, S. K.; Anal. Chem. 1989, 61, 1257A.

17. Brand-Williams, W.; Cuvelier, M. E.; Berset, C.; Lebensm. Wiss. U. Technol. 1995, 28, 25.

18. Bondet, V.; Brand-Williams, W.; Berset, C.; Lebensm. Wiss. U. Technol. 1997, 30, 609.

19. Duarte-Almeida, J. M.; Santos, R. J.; Genovese, M. I.; Lajolo, F. M.; Ciênc. Tecnol. Aliment. 2006, 26, 446.

20. Mabry, T. J.; Markham, K. R.; Thomas, M. B.; The Systematic Identification of Flavonoids, Springer-Verlag: New York, 1970.

21. Antolovich, M.; Prenzler, P. D.; Patsalides, E.; McDonald, S.; Robards, K.; Analyst 2002, 127, 183.

Received: June 15, 2007 Web Release Date: April 18, 2008

FAPESP helped in meeting the publication costs of this article. 


\section{HPLC Microfractionation of Flavones and Antioxidant (Radical Scavenging) Activity of Saccharum officinarum L.}

Fabiana C. Vila, Renata Colombo, Tatiana O. de Lira and Janete H. Yariwake* Instituto de Química de São Carlos, Universidade de São Paulo, 13560-970 São Carlos-SP, Brazil<smiles>O=c1cc(-c2ccc(O)c(O)c2)oc2c(Cl)c(O)cc(O)c12</smiles>

(1)<smiles>COc1ccc(-c2cc(=O)c3c(O)cc(O)c(Cl)c3o2)cc1O</smiles>

(2)<smiles>O=c1cc(-c2ccc(O)cc2)oc2c(Cl)c(O)cc(O)c12</smiles>

(3)<smiles>O=c1cc(-c2ccc(O)c(O)c2)oc2c(Cl)c(O)cc(O)c12</smiles>

(4)
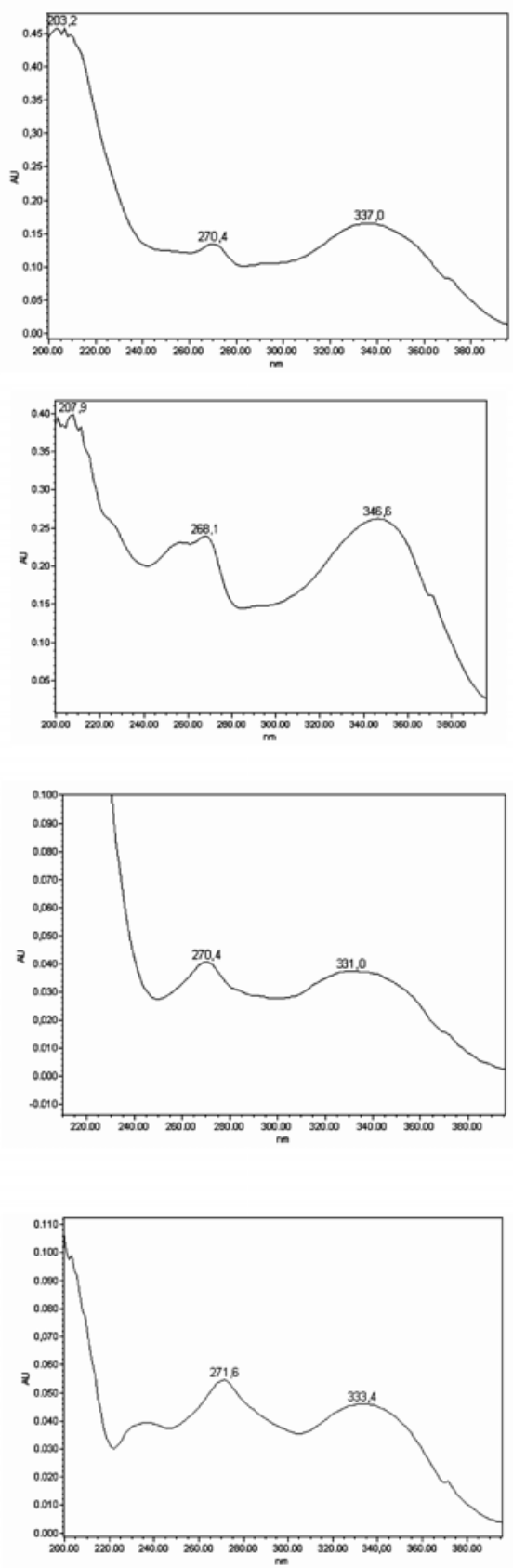

Figure S1. UV/PAD spectra and structure of Saccharum officinarum L. flavonoids. Numbering as in Figure 1 and Table 1. 
<smiles>COc1cc(-c2cc(=O)c3c(O)cc(O[R16](Cl)(Cl)Cl)cc3o2)cc(OC)c1O</smiles>

(5)<smiles>COc1cc(C(O)C(CO)Oc2c(OC)cc(-c3cc(=O)c4c(O)cc(OC5CCCCC5)cc4o3)cc2OC)ccc1O</smiles>

(6/7)<smiles>COc1cc(C(O)C(CO)Oc2c(OC)cc(-c3cc(=O)c4c(O)cc(O)cc4o3)cc2OC)ccc1O</smiles>

(8)<smiles>[14CH3]c1c(O)c(Cl)c(O)c2c(=O)cc(-c3ccc(O)cc3)oc12</smiles>

(9)
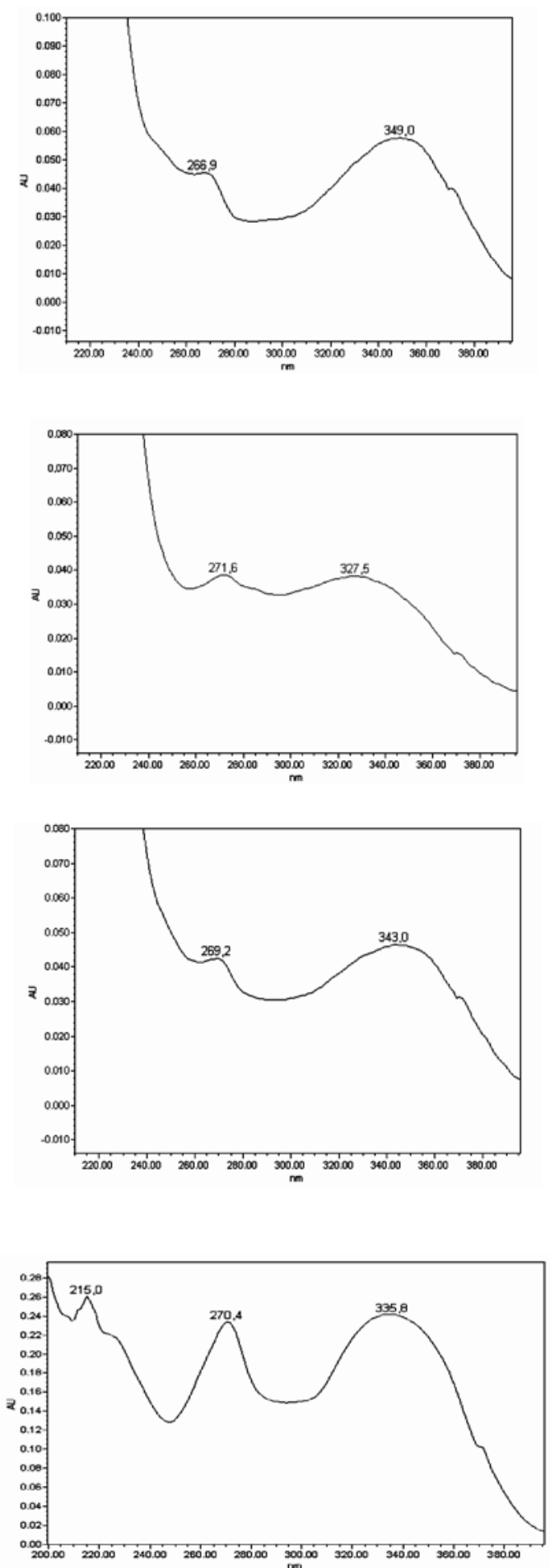

Figure S1. continuation 
<smiles>[14CH3]c1c(O)c(C(F)(Cl)Cl)c2oc(-c3ccc(O)cc3)cc(=O)c2c1O</smiles>

(10)<smiles>COc1cc(-c2cc(=O)c3c(O)cc(O)c(C(C)(C)C)c3o2)cc(O)c1OC</smiles>

(11)<smiles></smiles>

(12)<smiles>COc1cc(-c2cc(=O)c3c(O)cc(OC4CCCCC4)cc3o2)cc(OC)c1O</smiles>

(13)
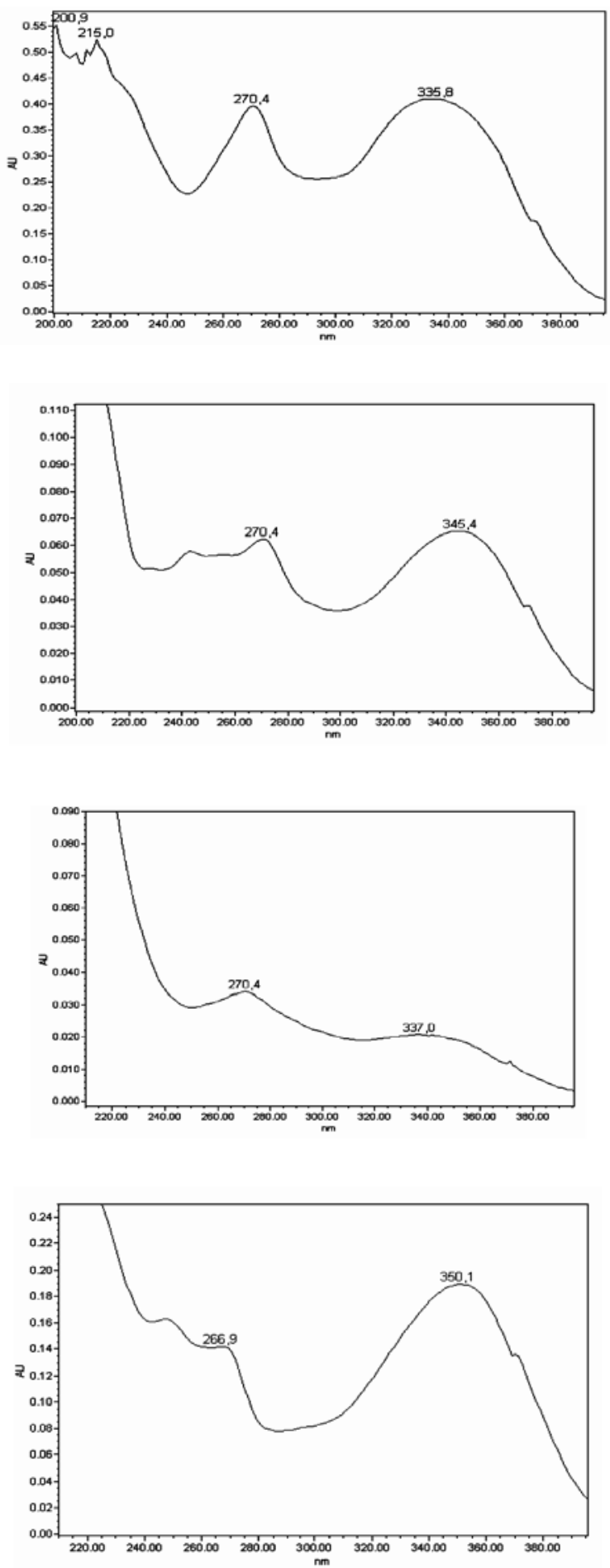

Figure S1. continuation 